\title{
Mycobacterium avium ss. paratuberculosis Zoonosis - The Hundred Year War - Beyond Crohn's Disease
}

\author{
Leonardo A. Sechi ${ }^{1}$ * and Coad Thomas Dow ${ }^{2,3}$ \\ 1 Department of Biomedical Sciences, University of Sassari, Sassari, Italy \\ ${ }^{2}$ McPherson Eye Research Institute, University of Wisconsin, Madison, WI, USA \\ ${ }^{3}$ Chippewa Valley Eye Clinic, Eau Claire, WI, USA
}

Edited by:

Amélia M. Sarmento, Universidade

Fernando Pessoa, Portugal

\section{Reviewed by:}

Willem Van Eden, Utrecht University, Netherlands

Hridayesh Prakash, University of

Hyderabad, India

*Correspondence:

Leonardo A. Sechi, Department of Biomedical Sciences, University of

Sassari, Viale San Pietro 43 b, Sassari 97100, Italy

e-mail:sechila@uniss.it
The factitive role of Mycobacterium avium ss. paratuberculosis (MAP) in Crohn's disease has been debated for more than a century. The controversy is due to the fact that Crohn's disease is so similar to a disease of MAP-infected ruminant animals, Johne's disease; and, though MAP can be readily detected in the infected ruminants, it is much more difficult to detect in humans. Molecular techniques that can detect MAP in pathologic Crohn's specimens as well as dedicated specialty labs successful in culturing MAP from Crohn's patients have provided strong argument for MAP's role in Crohn's disease. Perhaps more incriminating for MAP as a zoonotic agent is the increasing number of diseases with which MAP has been related: Blau syndrome, type 1 diabetes, Hashimoto thyroiditis, and multiple sclerosis. In this article, we debate about genetic susceptibility to mycobacterial infection and human exposure to MAP; moreover, it suggests that molecular mimicry between protein epitopes of MAP and human proteins is a likely bridge between infection and these autoimmune disorders.

Keywords: paratuberculosis, MAP, Crohn's, autoimmune, molecular mimicry, type 1 diabetes, autoimmune thyroiditis, multiple sclerosis

\section{INTRODUCTION}

In 1913, a concise description of what today is known as Crohn's disease was offered by Scottish surgeon Kennedy Dalziel (1). Twenty years earlier, in 1895, German veterinary Johne H. A. described the cause of an incurable profuse diarrhea in cattle. $\mathrm{He}$ noted acid-fast bacteria (most often indicating the organism that causes tuberculosis) that, when transferred to a guinea pig, did not cause tuberculosis (2). Johne first labeled the disease "pseudotuberculosis" and it eventually became known as paratuberculosis.

Infected cow's intestines had the same cobblestone aspect of Dalziel's patient and microscopically, the patient's and cattle's diseased intestines were so alike that Dalziel wrote that the tissue characteristics were:

... so similar as to justify a proposition that the diseases may be the same (1).

He hypothesized that the disease in cattle and the disease in people shared the same cause. The disease in humans was later named after Dr. Crohn who described a series of patients in 1932 (3).

The heart of this 100-year controversy revolves around the fact that the usual diagnostic techniques to detect bacteria are commonly inefficacious to detect Mycobacterium avium ss. paratuberculosis (MAP) in humans. A short explanation is that it is just very difficult to grow MAP from humans; and, MAP exists with a modified cell wall - the component of the bacterium that takes up the characteristic acid stain. In this state, the bacterium is no longer "acid fast" and cannot be detected microscopically. Recent work has identified the capacity of MAP to undergo a morphologic change to become spore-like. The spore morphotype survives heat and other stressors and may lead to an increased persistence in hosts and the environment (4).

Understanding the difficulty in detection and appreciating the work of specialty labs that have shown MAP bacteremia in Crohn's disease patients, there has been a warming to the association of MAP in Crohn's (5).

\section{MYCOBACTERIUM AVIUM SS. PARATUBERCULOSIS}

Mycobacterium avium ss. paratuberculosis is an acid-fast staining small rod-shaped bacterium $(6,7)$. As with members of the Mycobacteriaceae genus, its cell wall structure rich in complex lipids is unique. The tough and peculiar cell wall of mycobacteria is, in large part, responsible for the persistence of these bacteria, both in the environment and inside the host. Paradoxically, the pathogenic potential of mycobacteria increases as their growth rate decrease. In fact, slow-growing mycobacteria are more pathogenic than fast growing mycobacteria. Except the uncultivable Mycobacterium leprae (the cause of leprosy in humans), MAP has the slowest growth rate among harmful mycobacteria. After inoculum of infected samples from infected animals and incubated under optimal conditions, MAP colonies usually appear not before 3 months or more (8).

\section{MAP AND HUMAN EXPOSURE}

Mycobacterium avium ss. paratuberculosis can be found in pasteurized milk $(9,10)$, milk powder for children $(11)$, surface water (12-14), soil (12), cow manure that contaminates the soil and surface water, moreover cow manure is usually applied as fertilizer in different crops (15) and supply of drinking water (16) all 
contributing to human exposure. Soil and plants in grazing areas retain MAP; its DNA can be detected in the upper greens of plants, their roots and in the soil below the roots to a depth of $80 \mathrm{~cm}(17$, 18). MAP DNA was detected in over $80 \%$ of domestic water samples in Ohio (19). Chlorination and filtration may help to survive mycobacteria rather than eliminate these organisms by killing off their competitors (20). Moreover, mycobacteria organisms have been reported on tap water pipes (21) in biofilms (22) and plastic water bottles (23). One estimate is that mycobacteria could be present in drinking water in "massive numbers," on the amount of up to 700,000 or $7 \times 10^{5}$ organisms per liter of water (22). A recent study reported testing infant formula for MAP in 65 samples from 18 countries: $>40 \%$ tested positive for viable MAP (24).

\section{MAP AND HUMAN DISEASES}

In addition to Crohn's, MAP has been associated with multiple diseases: sarcoidosis and Blau syndrome (25), type 1 diabetes (2632), Hashimoto's thyroiditis (33-36), and multiple sclerosis (MS) (37-49). In autoimmune diabetes, thyroiditis, and MS, MAP is thought to induce pathology due to molecular mimicry between protein elements of itself and the targeted organ elements of the host, e.g., MAP 3865c and Znt8 in autoimmune (type 1) diabetes and thyroiditis $(31,35,36)$. Figure 1 shows how MAP may trigger autoimmune diseases.

If humans are so readily exposed to MAP, why is there not pervasive Crohn's disease and the other diseases mentioned in this article?

\section{GENETICS \\ CARD15}

A good example about the interaction between the genetic susceptibility and microbial infection can be found in Crohn's and Blau syndrome (50), both having polymorphisms within the CARD15 gene.

The gene was originally referred as the NOD2 gene and linkage studies have placed it on chromosome 16; now it is known as the CARD15 gene (51). The CARD15 gene is part of the ancestral innate immune system that recognizes bacteria peptidoglycan in particular mycobacterial glycolylated form of muramyl dipeptide MDP (52-54).

\section{CARD15, BLAU SYNDROME, AND CROHN'S DISEASE}

Insights into the consequence of genetic susceptibility to MAP infection may be observed in the rare inflammatory disease, Blau syndrome. This granulomatous inflammatory disorder is characterized by uveitis, arthritis, and dermatitis (50). Although rare, Blau syndrome has been of interest in recent medical literature because of the inherited or de novo mutation within the CARD15 gene, the same gene associated with Crohn's susceptibility (55, 56). However, Blau syndrome susceptibility component of the CARD15 gene is located at the nucleotide binding site domain $(55,56)$ whereas the Crohn's susceptibility can be found at the $\mathrm{N}$-terminal leucine-rich repeat domain (57-59).

Blau syndrome shares the same clinical characteristics of juvenile sarcoidosis; in fact, new CARD15 mutations are consistently found in cases of sporadic juvenile sarcoidosis - Blau syndrome $(60,61)$. For these reasons - the clinical appearance of sarcoidosis and a shared genetic susceptibility with Crohn's - it was proposed that MAP could have a role in Blau syndrome. A series of Blau tissues comprised of skin, synovial samples as well as Blau graulomas of the liver and kidney were tested for the presence of MAP. Six tissues of five patients representing three different families were all found to have MAP present in the tissue granulomas (25).

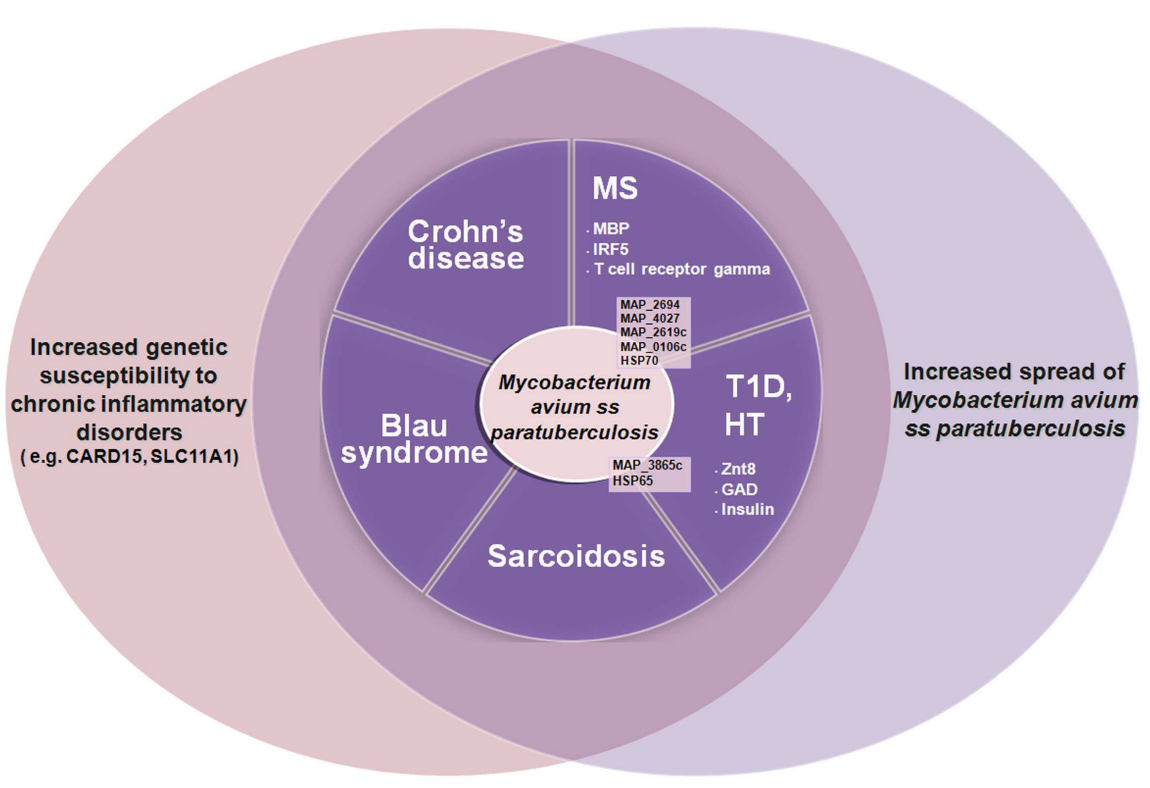

FIGURE 1 |The increased spread of Mycobacterium avium ss. paratuberculosis associated with genetic susceptibility to intracellular pathogens such as MAP (e.g., CARD15, SLC11A1) is leading to an increase of autoimmune diseases and inflammatory diseases such as type 1 diabetes (T1D), Hashimoto thyroiditis (HT), multiple sclerosis (MS), Crohn's disease, Blau syndrome, etc. Some of the MAP proteins involved are indicated (in black) with the human homologous target proteins (in white). 
The proposed etiopathology is that following MAP exposure, an individual genetically susceptible with mutations within the nucleotide binding domain of CARD15 will exhibit Blau syndrome whereas if the mutations are within the leucine-rich-repeat domain of the same gene, they may exhibit Crohn's disease. Moreover, it has been reported that CARD15 defects of the leucinerich-repeat domain, are associated in an aggressive phenotype of Crohn's disease (62). Recent work has reviewed the susceptibility genes associated with Crohn's (63).

\section{SLC11A1}

An additional gene linked with Crohn's susceptibility is the solute carrier 11a1 (SLC11A1) gene (64). SLC11A1 was previously identified as natural resistance-associated macrophage protein 1 (NRAMP1) (65). Polymorphisms within this gene and its promoter are recognized as having a role in the susceptibility of humans and animals to a number of infections, in particular mycobacterial infections, and it has been related to the susceptibility to autoimmune and inflammatory disease as well $(64,65)$. The SLC11A1 gene, located on chromosome $2 \mathrm{q} 35$, is around $14 \mathrm{~kb}$ in length. It encodes an integral membrane protein of 550 amino acids that is localized within the acidic endosomal and lysosomal compartment of resting macrophages (65).

The product of the SLC11A1 gene modulates the cellular environment in response to activation by intracellular pathogens by acidifying the phagosome thus killing the pathogen (66). As such, it plays a role in host innate immunity (67). Mutations of SLC11A1 may impair phagosome acidification yielding a permissive environment for the persistence of intracellular bacteria (68).

\section{SLC11A1 IN INFECTIOUS AND AUTOIMMUNE DISEASE}

Sarcoidosis, an other systemic disease associated with MAP, has been associated with polymorphisms of the SLC11A1 gene (69). Susceptibility to mycobacterial diseases, leprosy, and Buruli's ulcer were also associated with polymorphism of the SLC11A1 gene (70). Similar polymorphisms have been associated with Johne's disease (paratuberculosis) in cattle (71), goats (72), and sheep (73). A SLC11A1 defect mouse was created by researchers at the Belgium Pasteur Institute to develop a murine model for MAP infection (74).

Due to the capability of SLC11A1 to modulate innate immunity, it is not surprising that the relationship between polymorphisms in SLC11A1 and number of mycobacterial as well as autoimmune diseases has been explored (75). In addition to leprosy (76) and tuberculosis (77), an association is found in rheumatoid arthritis (78), MS (39, 79), inflammatory bowel disease (80-82), and type 1 diabetes - all diseases associated with $\operatorname{MAP}(83,84)$.

\section{MOLECULAR MIMICRY}

Molecular mimicry by a microorganisms has been hypothesized to initiate and exacerbate an autoimmune response through sequence or structural similarities with self-antigens $(85,86)$. Rheumatic fever is one of the best examples for molecular mimicry between group A streptococcus and host antigens leading to the glomerulonephritis and rheumatic heart disease $(87,88)$. The development of post-streptococcal sequelae is characterized by damage to the heart, joints, and the central nervous system (Sydenham's chorea). Damage of the heart is the most critical effect and is present in $30-45 \%$ of the cases - mostly causing damage to the heart valves.

\section{MAP AND TYPE 1 DIABETES}

Type 1 diabetes mellitus (T1DM) is an autoimmune disease manifest by progressive $\mathrm{T}$ cell-mediated autoimmune destruction of insulin-producing beta cells in the pancreatic islets of Langherans (89). Sechi in 2008 found the DNA of MAP in the blood of autoimmune (type 1) patients (32) but not non-autoimmune (type 2) diabetes $(27,28)$. Sechi also found an association of polymorphisms of the SLC11al gene and MAP in T1DM patients $(59,64,82)$.

While it may be intuitive to envision an occult presence of MAP as an infective agent producing a granulomatous lesion of Crohn's or sarcoidosis (Table 1A); it may be more difficult to assign a role for MAP in T1DM. The link connecting MAP and T1DM is molecular mimicry: protein elements of the pathogen "look like" elements of the host's endocrine pancreas; and immune responses directed at the pathogen sometimes may attack the host (Table 1B). Childhood exposure to cows milk-based infant formula is a strong risk factor for juvenile autoimmune diabetes (30)

Table 1 | (A) Map-related granulomatous diseases. (B) Map-associated autoimmune diseases.

\begin{tabular}{lll}
\hline (A) MAP-RELATED GRANULOMATOUS DISEASES \\
Disease & $\begin{array}{l}\text { Shared genetic } \\
\text { susceptibility }\end{array}$ & Reference \\
\hline Crohn's & CARD15, SLC11A1 & $(8,51,52,57,59,62,64)$ \\
Sarcoidosis & SLC11A1 & $(54,69)$ \\
Blau syndrome & CARD15 & $(52-56,60)$ \\
\hline
\end{tabular}

These granulomatous diseases are ones where evidence of MAP can be found in the granuloma. CARD15, caspase recruitment domain gene 15; SLC11a1, solute carrier 11 a 1 gene.

\begin{tabular}{lll}
\hline $\begin{array}{ll}\text { (B) MAP-ASSOCIATED AUTOIMMUNE DISEASES } \\
\text { Disease }\end{array}$ & Mimicking elements & Reference \\
\hline $\begin{array}{l}\text { Autoimmune } \\
\text { diabetes }\end{array}$ & $\begin{array}{l}\text { HSP65/GAD } \\
\text { MAP3865c/ZnT8 - 86-88, 90-94) } \\
\text { pancreatic }\end{array}$ & \\
$\begin{array}{l}\text { Autoimmune } \\
\text { thyroiditis }\end{array}$ & MAP3865c/ZnT8-thyroid & $(35,36)$ \\
Multiple & HSP70, MAP_2694, \\
sclerosis & MAP4027, MAP_2619c & \\
& $\begin{array}{l}\text { 352-61, MAP_0106c } \\
\text { protein 121-132 }\end{array}$ & \\
& & \\
\end{tabular}

These autoimmune diseases have autoantibodies. There are share molecular elements between MAP proteins and host organs. HSP65, heat shock protein 65; GAD, glutamic acid decarboxylase; MAP3865c, M. paratuberculosis protein 3865c; ZnT8, zinc transporter 8; HSP70, heat shock protein 70; MAP-0106c, M. paratuberculosis 0106c protein (aa. 121-132); MBP85-98, myelin basic protein (aa. 85-98). 
and, as mentioned in the "exposure to MAP" section of this paper, viable MAP is found in infant formula (24).

The proposed links is the mimicry of mycobacterial protein MAP3865c and the human homolog Znt8 $(31,35)$ along with the heat shock protein of MAP (HSP65) and pancreatic glutamic acid decarboxylase (GAD) (30). Different islet autoantibodies (aAbs) may characterize the period preceding T1D clinical onset, aAbs against islets antigens such as insulin, glutamic acid decarboxylase (GAD65), insulinoma associated protein-2, and zinc transporter 8 (ZnT8) may be detectable for months up to years before disease onset. Sechi et al., for example, reported that anti-MAP and anti-ZnT8 antibodies (Abs) targeting homologous membranespanning sequences are cross-reactive and capable of eliciting strong immune responses in T1D adult patients (91). One of the sequences was also able to elicit a $\mathrm{T}$ cell response (95). An association between MAP and T1D in children was demonstrated by Cossu et al. (96), Additional evidence of the involvement of MAP in the early phases at T1D onset appear from two studies $(91,92)$ where an association between Abs positive for ZnT8 and MAP homolog epitopes in Sardinian and Italian children at T1D onset was demonstrated. Moreover, Sechi et al. (93) reported a similar high antibody response against insulin epitopes and its MAP homologous peptides in children; those both at risk for T1D and at T1D onset. A review on the topic was previously reported (94).

\section{MAP AND AUTOIMMUNE THYROIDITIS}

The most common autoimmune disease associated to T1D is autoimmune thyroid disease, its frequency is estimated at $>90 \%$ among patients with T1D and autoimmune diseases (97). Different articles associate MAP to autoimmune (Hashimoto's) thyroiditis $(\mathrm{HT})(33,34)$. The same molecular mimicry principle is suggested as the link between MAP and Znt8, one of the organ-specific autoantigens of thyroiditis (33-36). Though ZnT8 is primarily expressed in pancreatic islet cells, it is also expressed in the follicular and para-follicular epithelial cells of the thyroid gland. In view of the evidence accounting for a cross-recognition of MAP3865c/ZnT8 homologs sequences in T1D subjects, and applying the theory which proposes MAP as an HT environmental trigger (acting trough a molecular mimicry mechanism) (35, 36), it is natural to consider MAP for a causal role in HT. Moreover, it has been reported that the occurrence of islet aAbs (especially Znt8) was associated with a positive titer of thyroid peroxidase antibodies (ATPO) in newly diagnosed adult-onset autoimmune diabetic patients (98).

\section{HEAT SHOCK PROTEINS}

Heat shock proteins (HSPs) are expressed at high level in response to environmental stress. They stabilize proteins and are involved in the folding of denatured proteins helping cells survive stressful conditions and promoting recovery (99). HSPs are synthesized to respond to the presence of invading pathogens. However, pathogens may also produce their HSPs. The increased expression of both self and infective stress proteins and the extensive sequence homology between microbial and human HSP (50$80 \%$ amino acid homology of mycobacterial HSP65 and human HSP60) have led to the concept that HSPs are involved in the etiology and pathogenesis of many immune-mediated disorders (100). Antibodies to mycobacterial HSPs have been found in various autoimmune diseases (101). Just to mention some, the mycobacterial $65 \mathrm{kDa}$ HSP has been associated to rheumatoid arthritis (102-104), autoimmune hepatitis (105), primary biliary cirrhosis (106), and systemic sclerosis (107). HSP65 has been reported in different vasculitis-associated systemic autoimmune diseases such as Kawasaki disease (108), Behcet's disease (109) Takayasu's arteritis (110), moreover, Hsp70 has also been associated with MS (90).

\section{MAP AND MULTIPLE SCLEROSIS}

Sechi et al. have published studies implicating MAP in MS (37-39, 41-49). Molecular mimicry and SLC11A1 associations are central to this association as well $(40,41)$. MAP has been associated with Epstein-Barr virus (EBV - thought to be one of the triggers of MS) (44): peptides of each microorganism (MAP and EBV) cross react with anti-myelin basic protein (MBP) (43) and interferon regulatory factor 5 (IRF5) in MS patients (48). Interferon-beta therapy influence antibody response against MAP (49). An extensive review on the topic has been previously published (46).

\section{THE FUTURE - MAP AND HUMAN DISEASE}

The role of MAP in Crohn's disease has progressed from controversial to conspicuous to compelling. The century-old striking similarities existing between Johne's and Crohn's diseases on a tissue level are now validated at cellular and molecular levels (90). There is an increasing awareness and call for resolution $(111,112)$. Improved testing strategies for ruminant herds such as metabolomic profiling (113) will aid in the public health approach to animal disease and sources of human exposure. On a limited basis, Crohn's disease has been treated successfully with antibiotics $(114,115)$. As the MAP/Crohn's debate resolves and as more diseases are linked to MAP, there will likely be a major shift in the public health approach to MAP and human disease. Early indications of such a shift are two clinical trials employing antimycobaterial drugs: clarithromycin, rifabutin, and clofazimine. One is a 60-center trial in Crohn's disease (116) and another is the same treatment for MS (117). Positive outcomes from efforts like these - curing Crohn's disease and MS with anti-mycobacterial medication as well as prevent autoimmune diabetes and thyroiditis - will further solidify the role of MAP as a zoonotic agent in human disease and, perhaps after more than a century, will resolve this medical controversy.

\section{ACKNOWLEDGMENTS}

The authors wish to acknowledge Magdalena Niegowska-Conforti for creating Figure 1. The research has been possible thanks to the following funds: Fondazione Banco di Sardegna year 2014; Regione Autonoma della Sardegna LR7, year 2010 and Grant supported by FISM entitled GEOEPIDEMIOLOGY OF MULTIPLE SCLEROSIS: THE ENVIRONMENTAL RISK FACTORS, Year 2012.

\section{REFERENCES}

1. Dalziel TK. Chronic interstitial enteritis. Br J Med (1913) 2:2756.

2. From history of Johne's disease. Johne's Information Center. (2014). Available from: http://www.johnes.org/history/index.html 
3. Crohn BB, Ginzburg L, Oppenheimer GD. Regional ileitis - a pathologic and clinical entity. JAMA (1932) 99(16):1323-9. doi:10.1001/jama.1932. 02740680019005

4. Lamont EA, Bannantine JP, Armién A, Ariyakumar DS, Sreevatsan S. Identification and characterization of a spore-like morphotype in chronically starved Mycobacterium avium subsp. paratuberculosis cultures. PLoS One (2012) 7(1):e30648. doi:10.1371/journal.pone.0030648

5. Agrawal G, Borody TJ, Chamberlin W. 'Global warming' to Mycobacterium avium subspecies paratuberculosis. Future Microbiol (2014) 9(7):829-32. doi:10.2217/fmb.14.52

6. Bhamidi S, Scherman MS, Jones V, Crick DC, Belisle JT, Brennan PJ, et al. Detailed structural and quantitative analysis reveals the spatial organization of the cell walls of in vivo grown Mycobacterium leprae and in vitro grown Mycobacterium tuberculosis. J Biol Chem (2011) 286(26):23168-77. doi:10.1074/jbc.M110.210534

7. Niederweis M, Danilchanka O, Huff J, Hoffmann C, Engelhardt H. Mycobacterial outer membranes: in search of proteins. Trends Microbiol (2010) 18(3):109-16. doi:10.1016/j.tim.2009.12.005

8. Collins MT. Paratuberculosis: review of present knowledge. Acta Vet Scand (2003) 44:217-21.

9. Millar D, Ford J, Sanderson J, Withey S, Tizard M, Doran T, et al. IS900 PCR to detect Mycobacterium paratuberculosis in retail supplies of whole pasteurized'cows' milk in England and Wales. Appl Environ Microbiol (1996) 62:3446-52.

10. Ellingson JL, Anderson JL, Koziczkowski JJ, Radcliff RP, Sloan SJ, Allen SE, et al. Detection of viable Mycobacterium avium subsp. paratuberculosis in retail pasteurized whole milk by two culture methods and PCR. J Food Prot (2005) 68(5):966-72.

11. Hruska K, Bartos M, Kralik P, Pavlik I. Mycobacterium avium subsp. paratuberculosis in powdered infant milk: paratuberculosis in cattle - the public health problem to be solved. Vet Med Czech (2005) 50(8):327-35.

12. Pickup RW, Rhodes G, Arnott S, Sidi-Boumedine K, Bull TJ, Weightman A, et al. Mycobacterium avium subsp. paratuberculosis in the catchment area and water of the River Taff in South Wales, United Kingdom, and its potential relationship to clustering of Crohn's disease cases in the city of Cardiff. Appl Environ Microbiol (2005) 71:2130-9. doi:10.1128/AEM.71.4. 2130-2139.2005

13. Whan L, Ball HJ, Grant IR, Rowe MT. Occurrence of Mycobacterium avium subsp. paratuberculosis in untreated water in Northern Ireland. Appl Environ Microbiol (2006) 71:7107-12. doi:10.1128/AEM.71.11.7107-7112.2005

14. Pickup RW, Rhodes G, Bull TJ, Arnott S, Sidi-Boumedine K, Hurley M, et al. Mycobacterium avium subsp. paratuberculosis in lake catchments, in river water abstracted for domestic use, and in effluent from domestic sewage treatment works: diverse opportunities for environmental cycling and human exposure. Appl Environ Microbiol (2006) 72:4067-77. doi:10.1128/AEM. 02490-05

15. Grewal SK, Rajeev S, Sreevatsan S, Michel FC Jr. Persistence of Mycobacterium avium subsp. paratuberculosis and other zoonotic pathogens during simulated composting, manure packing, and liquid storage of dairy manure. Appl Environ Microbiol (2006) 72:565-74. doi:10.1128/AEM.72.1.565-574.2006

16. Collins MT, Miliotis MD, Bier JW. International Handbook of Foodborne Pathogens. Boca Raton, FL: CRC Press (2003). 17 p

17. Kaevska M, Lvoncik S, Lamka J, Pavlik I, Slana I. Spread of Mycobacterium avium subsp. paratuberculosis through soil and grass on a Mouflon (Ovis aries) pasture. Curr Microbiol (2014) 69(4):495-500. doi:10.1007/s00284-0140618-418

18. Pribylova R, Slana I, Kaevska M, Lamka J, Babak V, Jandak J, et al. Soil and plant contamination with Mycobacterium avium subsp. paratuberculosis after exposure to naturally contaminated mouflon feces. Curr Microbiol (2011) 62(5):1405-10. doi:10.1007/s00284-011-9875-7

19. Beumer A, King D, Donohue M, Mistry J, Covert T, Pfaller S. Detection of Mycobacterium avium subsp. paratuberculosis in drinking water and biofilms by quantitative PCR. Appl Environ Microbiol (2010) 76(21):7367-70. doi:10.1128/AEM.00730-10

20. Falkinham JOIII. Factors influencing the chlorine susceptibility of Mycobacterium avium, Mycobacterium intracellulare, and Mycobacterium scrofulaceum. Appl Environ Microbiol (2003) 69:5685-9. doi:10.1128/AEM.69.9. 5685-5689.2003
21. Falkinham JO III, Norton CD, LeChevallier MW. Factors influencing numbers of Mycobacterium avium, Mycobacterium intracellulare, and other mycobacteria in drinking water distribution systems. Appl Environ Microbiol (2001) 67:1225-31. doi:10.1128/AEM.67.3.1225-1231.2001

22. Vaerewijck MJ, Huys G, Palomino JC, Swings J, Portaels F. Mycobacteria in drinking water distribution systems: ecology and significance for human health. FEMS Microbiol Rev (2005) 29:911-34. doi:10.1016/j.femsre. 2005.02.001

23. Tatchou-Nyamsi-Konig JA, Dailloux M, Block JC. Survival of Mycobacterium avium attached to polyethylene terephtalate (PET) water bottles. J Appl Microbiol (2009) 106:825-32. doi:10.1111/j.1365-2672.2008.04050.x

24. Grant I, Foddai A, Kunkel B, Collins MT. Detection of viable Mycobacterium avium subsp. paratuberculosis (MAP) in infant formula. Presented at the 12th International Colloquium on Paratuberculosis. Parma (2014).

25. Dow CT, Ellingson JL. Detection of Mycobacterium avium ss. Paratuberculosis in Blau syndrome tissues. Autoimmune Dis (2010) 20(2010):127692. doi: $10.4061 / 2010 / 127692$

26. Cossu A, Rosu V, Paccagnini D, Cossu D, Pacifico A, Sechi LA. MAP3738c and MptD are specific tags of Mycobacterium avium subsp. paratuberculosis infection in type I diabetes mellitus. Clin Immunol (2011) 141(1):49-57. doi:10.1016/j.clim.2011.05.002

27. Rosu V, Ahmed N, Paccagnini D, Pacifico A, Zanetti S, Sechi LA. Mycobacterium avium subspecies paratuberculosis is not associated with type-2 diabetes mellitus. Ann Clin Microbiol Antimicrob (2008) 22(7):9. doi:10.1186/ 1476-0711-7-9

28. Rosu V, Ahmed N, Paccagnini D, Gerlach G, Fadda G, Hasnain SE, et al. Specific immunoassays confirm association of Mycobacterium avium Subsp. paratuberculosis with type-1 but not type-2 diabetes mellitus. PLoS One (2009) 4(2):e4386. doi:10.1371/journal.pone.0004386

29. Sechi LA, Rosu V, Pacifico A, Fadda G, Ahmed N, Zanetti S. Humoral immune responses of type 1 diabetes patients to Mycobacterium avium subsp. paratuberculosis lend support to the infectious trigger hypothesis. Clin Vaccine Immunol (2008) 15(2):320-6. doi:10.1128/CVI.00381-07

30. Dow CT. Paratuberculosis and type I diabetes: is this the trigger? Med Hypotheses (2006) 67(4):782-5. doi:10.1016/j.mehy.2006.04.029

31. Masala S, Paccagnini D, Cossu D, Brezar V, Pacifico A, Ahmed N, et al. Antibodies recognizing Mycobacterium avium paratuberculosis epitopes cross-react with the beta-cell antigen ZnT8 in Sardinian type 1 diabetic patients. PLoS One (2011) 6(10):e26931. doi:10.1371/journal.pone.0026931

32. Sechi LA, Paccagnini D, Salza S, Pacifico A, Ahmed N, Zanetti S. Mycobacterium avium subspecies paratuberculosis bacteremia in type 1 diabetes mellitus: an infectious trigger? Clin Infect Dis (2008) 46(1):148-9. doi:10.1086/ 524084

33. D’Amore M, Lisi S, Sisto M, Cucci L, Dow CT. Molecular identification of Mycobacterium avium subspecies paratuberculosis in an Italian patient with Hashimoto's thyroiditis and Melkersson-Rosenthal syndrome. J Med Microbiol (2010) 59(Pt 1):137-9. doi:10.1099/jmm.0.013474-0

34. Sisto M, Cucci L, D’Amore M, Dow TC, Mitolo V, Lisi S. Proposing a relationship between Mycobacterium avium subspecies paratuberculosis infection and Hashimoto's thyroiditis. Scand J Infect Dis (2010) 42(10):787-90. doi:10.3109/00365541003762306

35. Masala S, Cossu D, Palermo M, Sechi LA. Recognition of zinc transporter 8 and MAP3865c homologous epitopes by Hashimoto's thyroiditis subjects from Sardinia: a common target with type 1 diabetes? PLoS One (2014) 9(5):e97621. doi:10.1371/journal.pone.0097621

36. Pinna A, Masala S, Blasetti F, Maiore I, Cossu D, Paccagnini D, et al. Detection of serum antibodies cross-reacting with Mycobacterium avium subspecies paratuberculosis and beta-cell antigen zinc transporter 8 homologous peptides in patients with high-risk proliferative diabetic retinopathy. PLoS One (2014) 9(9):e107802. doi:10.1371/journal.pone.0107802

37. Cossu D, Cocco E, Paccagnini D, Masala S, Ahmed N, Frau J, et al. Association of Mycobacterium avium subsp. paratuberculosis with multiple sclerosis in Sardinian patients. PLoS One (2011) 6(4):e18482. doi:10.1371/journal.pone. 0018482

38. Cossu D, Mameli G, Masala S, Cocco E, Frau J, Marrosu MG, et al. Evaluation of the humoral response against mycobacterial peptides, homologous to MOG35-55, in multiple sclerosis patients. J Neurol Sci (2014) 347(1-2):78-81. doi:10.1016/j.jns.2014.09.023 
39. Cossu D, Masala S, Cocco E, Paccagnini D, Tranquilli S, Frau J, et al. Association of Mycobacterium avium subsp. paratuberculosis and SLC11A1 polymorphisms in Sardinian multiple sclerosis patients. J Infect Dev Ctries (2013) 7(3):203-7. doi:10.3855/jidc.2737

40. Gazouli M, Sechi L, Paccagnini D, Sotgiu S, Arru G, Nasioulas G, et al. NRAMP1 polymorphism and viral factors in Sardinian multiple sclerosis patients. Can J Neurol Sci (2008) 35(4):491-4. doi:10.1017/S0317167100009173

41. Ates O, Kurt S, Bozkurt N, Karaer H. NRAMP1 (SLC11A1) variants: genetic susceptibility to multiple sclerosis. J Clin Immunol (2010) 30(4):583-6. doi:10.1007/s10875-010-9422-5

42. Cossu D, Masala S, Cocco E, Paccagnini D, Frau J, Marrosu MG, et al. Are Mycobacterium avium subsp. paratuberculosis and Epstein-Barr virus triggers of multiple sclerosis in Sardinia? Mult Scler (2012) 18(8):1181-4. doi:10.1177/1352458511433430

43. Mameli G, Cossu D, Cocco E, Masala S, Frau J, Marrosu MG, et al. EpsteinBarr virus and Mycobacterium avium subsp. paratuberculosis peptides are cross recognized by anti-myelin basic protein antibodies in multiple sclerosis patients. J Neuroimmunol (2014) 270(1-2):51-5. doi:10.1016/j.jneuroim. 2014.02.013

44. Mameli G, Cossu D, Cocco E, Masala S, Frau J, Marrosu MG, et al. EBNA-1 IgG titers in Sardinian multiple sclerosis patients and controls. J Neuroimmunol (2013) 264(1-2):120-2. doi:10.1016/j.jneuroim.2013.07.017

45. Cossu D, Masala S, Frau J, Mameli G, Marrosu MG, Cocco E, et al. Antigenic epitopes of MAP2694 homologous to T-cell receptor gamma-chain are highly recognized in multiple sclerosis Sardinian patients. Mol Immunol (2014) 57(2):138-40. doi:10.1016/j.molimm.2013.09.001

46. Cossu D, Masala S, Sechi LA. A Sardinian map for multiple sclerosis. Future Microbiol (2013) 8(2):223-32. doi:10.2217/fmb.12.135

47. Soares RM, Dias AT, De Castro SB, Alves CC, Evangelista MG, Da Silva LC, et al. Optical neuritis induced by different concentrations of myelin oligodendrocyte glycoprotein presents different profiles of the inflammatory process. Autoimmunity (2013) 46(7):480-5. doi:10.3109/08916934.2013.796938

48. Cossu D, Mameli G, Galleri G, Cocco E, Masala S, Frau J, et al. Human interferon regulatory factor 5 homologous epitopes of Epstein-Barr virus and Mycobacterium avium subsp. paratuberculosis induce a specific humoral and cellular immune response in multiple sclerosis patients. Mult Scler (2014) 12.

49. Frau J, Cossu D, Coghe G, Lorefice L, Fenu G, Porcu G, et al. Role of interferon-beta in Mycobacterium avium subspecies paratuberculosis antibody response in Sardinian MS patients. J Neurol Sci (2015) 349(1-2):249-50. doi:10.1016/j.jns.2015.01.004

50. Blau B. Familial granulomatous arthritis, iritis, and rash. J Pediatr (1985) 107(5):689-93. doi:10.1016/S0022-3476(85)80394-2

51. Hampe J, Grebe J, Nikolaus S, Solberg C, Croucher PJ, Mascheretti S, et al. Association of NOD2 (CARD 15) genotype with clinical course of Crohn's disease: a cohort study. Lancet (2002) 359(9318):1661-5. doi:10.1016/S0140-6736(02) 08590-2

52. Inohara N, Ogura Y, Fontalba A, Gutierrez O, Pons F, Crespo J, et al. Host recognition of bacterial muramyl dipeptide mediated through NOD2: implications for Crohn's disease. J Biol Chem (2003) 278(8):5509-12. doi:10.1074/ jbc.C200673200

53. Hansen JM, Golchin SA, Veyrier FJ, Domenech P, Boneca IG, Azad AK, et al. $\mathrm{N}$-glycolylated peptidoglycan contributes to the immunogenicity but not pathogenicity of Mycobacterium tuberculosis. J Infect Dis (2014) 209(7):1045-54. doi:10.1093/infdis/jit622

54. Kanazawa N, Okafuji I, Kambe N, Nishikomori R, Nakata-Hizume M, Nagai S, et al. Early-onset sarcoidosis and CARD15 mutations with constitutive nuclear factor- $\kappa \mathrm{B}$ activation: common genetic etiology with Blau syndrome. Blood (2005) 105(3):1195-7. doi:10.1182/blood-2004-07-2972

55. Miceli-Richard C, Lesage S, Rybojad M, Prieur AM, Manouvrier-Hanu S, Häfner R, et al. CARD15 mutations in Blau syndrome. Nat Genet (2001) 29(1):19-20. doi:10.1038/ng720

56. Wang X, Kuivaniemi H, Bonavita G, Mutkus L, Mau U, Blau E, et al. CARD15 mutations in familial granulomatosis syndromes: a study of the original Blau syndrome kindred and other families with large-vessel arteritis and cranial neuropathy. Arthritis Rheum (2002) 46(11):3041-5. doi:10.1002/art.10618

57. Hugot J-P, Chamaillard M, Zouali H, Lesage S, Cézard JP, Belaiche J, et al. Association of NOD2 leucine-rich repeat variants with susceptibility to Crohn's disease. Nature (2001) 411(6837):599-603. doi:10.1038/35079107
58. Lesage S, Zouali H, Cézard JP, Colombel JF, Belaiche J, Almer S, et al. CARD15/NOD2 mutational analysis and genotype-phenotype correlation in 612 patients with inflammatory bowel disease. Am J Hum Genet (2002) 70(4):845-57. doi:10.1086/339432

59. Sechi LA, Gazouli M, Ikonomopoulos J, Lukas JC, Scanu AM, Ahmed N, et al. Mycobacterium avium subsp. paratuberculosis, genetic susceptibility to Crohn's disease, and Sardinians: the way ahead. J Clin Microbiol (2005) 43(10):5275-7. doi:10.1128/JCM.43.10.5275-5277.2005

60. Rose CD, Doyle TM, McIlvain-Simpson G, Coffman JE, Rosenbaum JT, Davey MP, et al. Blau syndrome mutation of CARD15/NOD2 in sporadic early onset granulomatous arthritis. J Rheumatol (2005) 32(2):373-5.

61. Wouters CH, Maes A, Foley KP, Bertin J, Rose CD. Blau syndrome, the prototypic auto-inflammatory granulomatous disease. Pediatr Rheumatol Online J (2014) 12:33. doi:10.1186/1546-0096-12-33

62. Lacher M, Helmbrecht J, Schroepf S, Koletzko S, Ballauff A, Classen M, et al. NOD2 mutations predict the risk for surgery in pediatric-onset Crohn's disease. J Pediatr Surg (2010) 45(8):1591-7. doi:10.1016/j.jpedsurg. 2009.10.046

63. Franke A, McGovern DP, Barrett JC, Wang K, Radford-Smith GL, Ahmad $\mathrm{T}$, et al. Genome-wide meta-analysis increases to 71 the number of confirmed Crohn's disease susceptibility loci. Nat Genet (2010) 42(12):1118-25. doi:10.1038/ng.717

64. Sechi LA, Gazouli M, Sieswerda LE, Molicotti P, Ahmed N, Ikonomopoulos J, et al. Relationship between Crohn's disease, infection with Mycobacterium avium subspecies paratuberculosis and SLC11A1 gene polymorphisms in Sardinian patients. World J Gastroenterol (2006) 12(44):7161-4.

65. Canonne-Hergaux F, Gruenheid S, Govoni G, Gros P. (1999) The Nramp1 protein and its role in resistance to infection and macrophage function. Proc Assoc Am Physicians (1999) 111:283-9. doi:10.1046/j.1525-1381.1999.99236.x

66. Lapham AS, Phillips ES, Barton CH. Transcriptional control of Nramp1: a paradigm for the repressive action of c-Myc. Biochem Soc Trans (2004) 32(Pt 6):1084-6. doi:10.1042/BST0321084

67. Wyllie S, Seu P, Goss JA. The natural resistance-associatedmacrophage protein 1 Slc1lal (formerly Nramp1) and iron metabolism in macrophages. Microbes Infect (2002) 4(3):351-9. doi:10.1016/S1286-4579(02)01548-4

68. Hackam DJ, Rotstein OD, Zhang W, Gruenheid S, Gros P, Grinstein S. Host resistance to intracellular infection: mutation of natural resistance-associated macrophage protein 1 (Nramp1) impairs phagosomal acidification. J Exp Med (1998) 188(2):351-64. doi:10.1084/jem.188.2.351

69. Dubaniewicz A, Jamieson SE, Dubaniewicz-Wybieralska M, Fakiola M, Nancy Miller E, Blackwell JM. Association between SLC11A1 (formerly NRAMP1) and the risk of sarcoidosis in Poland. Eur J Hum Genet (2005) 13(7):829-34. doi:10.1038/sj.ejhg. 5201370

70. Stienstra Y, van der Werf TS, Oosterom E, Nolte IM, van der GraafWT, Etuaful S, et al. Susceptibility to Buruli ulcer is associated with the SLC11A1 (NRAMP1) D543N polymorphism. Genes Immun (2006) 7(3):185-9. doi:10.1038/sj.gene. 6364281

71. Ruiz-Larrañaga O, Garrido JM, Manzano C, Iriondo M, Molina E, Gil A, et al. Identification of single nucleotide polymorphisms in the bovine solute carrier family 11 member 1 (SLC11A1) gene and their association with infection by Mycobacterium avium subspecies paratuberculosis. J Dairy Sci (2010) 93(4):1713-21. doi:10.3168/jds.2009-2438

72. Korou LM, Liandris E, Gazouli M, Ikonomopoulos J. Investigation of the association of the SLC11A1 gene with resistance/sensitivity of goats (Capra hircus) to paratuberculosis. Vet Microbiol (2010) 144(3-4):353-8. doi:10.1016/j. vetmic.2010.01.009

73. Purdie AC, Plain KM, Begg DJ, de Silva K, Whittington RJ. Candidate gene and genome-wide association studies of Mycobacterium avium subsp. paratuberculosis infection in cattle and sheep: a review. Comp Immunol Microbiol Infect Dis (2011) 34(3):197-208. doi:10.1016/j.cimid.2010.12.003

74. Roupie V, Rosseels V, Piersoel V, Zinniel DK, Barletta RG, Huygen K. Genetic resistance of mice to Mycobacterium paratuberculosis is influenced by Slc1lal at the early but not at the late stage of infection. Infect Immun (2008) 76(5):2099-105. doi:10.1128/IAI.01137-07

75. Blackwell JM, Searle S, Mohamed H, White JK. Divalent cation transport and susceptibility to infectious and autoimmune disease: continuation of the Ity/Lsh/Bcg/Nramp1/Slc1lal gene story. Immunol Lett (2003) 85(2):197-203. doi:10.1016/S0165-2478(02)00231-6 
76. Hatta M, Ratnawati, Tanaka M, Ito J, Shirakawa T, Kawabata M. NRAMP1/SLC11A1 gene polymorphisms and host susceptibility to Mycobacterium tuberculosis and M. leprae in South Sulawesi, Indonesia. Southeast Asian J Trop Med Public Health (2010) 41(2):386-94.

77. Bellamy R, Ruwende C, Corrah T, McAdam KP, Whittle HC, Hill AV. Variations in the NRAMP1 gene and susceptibility to tuberculosis in West Africans. NEngl J Med (1998) 338:640-4. doi:10.1056/NEJM199803053381002

78. Ates O, Dalyan L, Musellim B, Hatemi G, Turker H, Ongen G, et al. NRAMP1 (SLC11A1) gene polymorphisms that correlate with autoimmune versus infectious disease susceptibility in tuberculosis and rheumatoid arthritis. Int I Immunogenet (2009) 36:15-9. doi:10.1111/j.1744-313X.2008.00814.x

79. Kotze MJ, de Villiers JN, Rooney RN, Grobbelaar JJ, Mansvelt EP, Bouwens CS, et al. Analysis of the NRAMP1 gene implicated in iron transport: association with multiple sclerosis and age effects. Blood Cells Mol Dis (2001) 27:44-53. doi:10.1006/bcmd.2000.0349

80. Gazouli M, Atsaves V, Mantzaris G, Economou M, Nasioulas G, Evangelou K, et al. Role of functional polymorphisms of NRAMP1 gene for the development of Crohn's disease. Inflamm Bowel Dis (2008) 14:1323-30. doi:10.1002/ ibd. 20488

81. Kotlowski R, Bernstein CN, Silverberg MS, Krause DO. Population-based casecontrol study of alpha 1-antitrypsin and SLC11A1 in Crohn's disease and ulcerative colitis. Inflamm Bowel Dis (2008) 14:1112-7. doi:10.1002/ibd.20425

82. Paccagnini D, Sieswerda L, Rosu V, Masala S, Pacifico A, Gazouli M, et al. Linking chronic infection and autoimmune diseases: Mycobacterium avium subspecies par atuberculosis, SLC11A1 polymorphisms and type-1 diabetes mellitus. PLoS One (2009) 214(9):e7109. doi:10.1371/journal.pone.0007109

83. Masala S, Cossu D, Pacifico A, Molicotti P, Sechi LA. Sardinian type 1 diabetes patients, transthyretin and Mycobacterium avium subspecies paratuberculosis infection. Gut Pathog (2012) 4(1):24. doi:10.1186/1757-4749-4-24

84. Takahashi K, Satoh J, Kojima Y, Negoro K, Hirai M, Hinokio Y, et al. Promoter polymorphism of SLC11A1 (formerly NRAMP1) confers susceptibility to autoimmune type 1 diabetes mellitus in Japanese. Tissue Antigens (2004) 63(3):231-6. doi:10.1111/j.1399-0039.2004.000172.x

85. Oldstone MB. Molecular mimicry and autoimmune disease. Cell (1987) 50(6):819-20. doi:10.1016/0092-8674(87)90507-1

86. Raska M, Weigl E. Heat shock proteins in autoimmune diseases. Biomed Pap Med Fac Univ Palacky Olomouc Czech Repub (2005) 149(2):243-9. doi:10.5507/bp.2005.033

87. Guilherme L, Faé K, Oshiro SE, Kalil J. Molecular pathogenesis of rheumatic fever and rheumatic heart disease. Expert Rev Mol Med (2005) 7(28):1-15. doi:10.1017/S146239940501015X

88. Kaplan MH, SVEC KH. Immunologic relation of streptococcal and tissue antigens. III. Presence in human sera of streptococcal antibody cross-reactive with heart tissue. Association with streptococcal infection, rheumatic fever, and glomerulonephritis. J Exp Med (1964) 119:65166. doi:10.1084/jem.119.4.651

89. Eisenbarth GS. Type I diabetes mellitus. A chronic autoimmune disease. NEngl J Med (1986) 314(21):1360-8. doi:10.1056/NEJM198605223142106

90. Davis W, Madsen-Bouterse S. Crohn's disease and Mycobacterium avium subsp. paratuberculosis: the need for a study is long overdue. Vet Immunol Immunopathol (2012) 145(1-2):1-6. doi:10.1016/j.vetimm.2011.12.005

91. Masala S, Zedda MA, Cossu D, Ripoli C, Palermo M, Sechi LA. Zinc transporte 8 and MAP3865c homologous epitopes are recognized at T1D onset in Sardinian children. PLoS One (2013) 8(5):e63371. doi:10.1371/journal.pone.0063371

92. Masala S, Cossu D, Piccinini S, Rapini N, Massimi A, Porzio O, et al. Recognition of zinc transporter 8 and MAP3865c homologous epitopes by new-onset type 1 diabetes children from continental Italy. Acta Diabetol (2014) 51(4):577-85 doi:10.1007/s00592-014-0558-2

93. Masala S, Cossu D, Piccinini S, Rapini N, Mameli G, Manca Bitti ML, et al. Proinsulin and MAP3865c homologous epitopes are a target of antibody response in new-onset type 1 diabetes children from continental Italy. Pediatr Diabetes J (2015). (in press)

94. Rani PS, Sechi LA, Ahmed N. Mycobacterium avium subsp. paratuberculosis as a trigger of type-1 diabetes: destination Sardinia, or beyond? Gut Pathog (2010) 2(1):1. doi:10.1186/1757-4749-2-1

95. Scotto M, Afonso G, Larger E, Raverdy C, Lemonnier FA, Carel JC, et al Zinc transporter (ZnT)8(186-194) is an immunodominant CD8+ T cell epitope in HLA-A2+ type 1 diabetic patients. Diabetologia (2012) 55(7):2026-31. doi:10.1007/s00125-012-2543-z
96. Cossu A, Ferrannini E, Fallahi P, Antonelli A, Sechi LA. Antibodies recognizing specific Mycobacterium avium subsp. paratuberculosis's MAP3738c protein in type 1 diabetes mellitus children are associated with serum Th1 (CXCL10) chemokine. Cytokine (2013) 61(2):337-9. doi:10.1016/j.cyto.2012.11.008

97. Kawasaki E. Type 1 diabetes and autoimmunity. Clin Pediatr Endocrinol (2014) 23(4):99-105. doi:10.1297/cpe.23.99

98. Rogowicz-Frontczak A, Zozuliłska-Ziołkiewicz D, Litwinowicz M, Niedzwiecki P, Wyka K, Wierusz-Wysocka B. Are zinc transporter type 8 antibodies a marker of autoimmune thyroiditis in non-obese adults with new-onset diabetes? Eur J Endocrinol (2014);170(4):651-8. doi:10.1530/EJE-13-0901

99. Parsell DA, Lindquist $S$. The function of heat shock proteins in stress tolerance: degradation and reactivation of damaged proteins. Annu Rev Genet (1993) 27:437-96. doi:10.1146/annurev.ge.27.120193.002253

100. Lamb JR, Young DB. T cell recognition of stress proteins. A link between infectious and autoimmune disease. Mol Biol Med (1990) 7(4):311-21.

101. Jarjour WN, Jeffries BD, Davis JS IV, Welch WJ, Mimura T, Winfield JB. Autoantibodies to human stress proteins. A survey of various rheumatic and other inflammatory diseases. Arthritis Rheum (1991) 34(9):1133-8. doi:10.1002/art. 1780340909

102. Moudgil KD, Chang TT, Eradat H, Chen AM, Gupta RS, Brahn E, et al. Diversification of $\mathrm{T}$ cell responses to carboxy-terminal determinants within the 65 $\mathrm{kD}$ heat-shock protein is involved in regulation of autoimmune arthritis. J Exp Med (1997) 185(7):1307-16. doi:10.1084/jem.185.7.1307

103. Cossu D, Masala S, Frau J, Cocco E, Marrosu MG, Sechi LA. Anti Mycobacterium avium subsp. paratuberculosis heat shock protein 70 antibodies in the sera of Sardinian patients with multiple sclerosis. J Neurol Sci (2013) 335(1-2):131-3. doi:10.1016/j.jns.2013.09.011

104. Quayle AJ, Wilson KB, Li SG, Kjeldsen-Kragh J, Oftung F, Shinnick T, et al. Peptide recognition, $\mathrm{T}$ cell receptor usage and HLA restriction elements of human heat-shock protein (hsp) 60 and mycobacterial $65 \mathrm{kDa}$ hsp-reactive $\mathrm{T}$ cell clones from rheumatoid synovial fluid. Eur J Immunol (1992) 22(5):1315-22. doi:10.1002/eji.1830220529

105. Miyata M, Kogure A, Sato H, Kodama E, Watanabe H, Ohira H, et al. Detection of antibodies to $65 \mathrm{KD}$ heat shock protein and to human superoxide dismutase in autoimmune hepatitis-molecular mimicry between $65 \mathrm{KD}$ heat shock protein and superoxide dismutase. Clin Rheumatol (1995) 14(6):673-7. doi:10.1007/BF02207935

106. Vilagut L, Pares A, Vinas O, Vila J, Jiménez de Anta MT, Rodés J. Antibodies to mycobacterial $65 \mathrm{kD}$ heat shock protein cross-react with the main mitochondrial antigens in patients with primary biliary cirrhosis. Eur J Clin Invest (1997) 27(8):667-72. doi:10.1046/j.1365-2362.1997.1690724.x

107. Danieli MG, Candela M, Ricciatti AM, Reginelli R, Danieli G, Cohen IR, et al. Antibodies to mycobacterial $65 \mathrm{kDa}$ heat shock protein in systemic sclerosis (scleroderma). J Autoimmun (1992) 5(4):443-5. doi:10.1016/0896-8411(92) 90004-A

108. Yokota S, Tsubaki S, Kuriyama T, Shimizu H, Ibe M, Mitsuda T, et al. Presence in Kawasaki disease of antibodies to mycobacterial heatshock protein HSP65 and autoantibodies to epitopes of human HSP65 cognate antigen. Clin Immunol Immunopathol (1993) 67:163-70. doi:10.1006/clin.1993.1060

109. Direskeneli H, Saruhan-Direskeneli G. The role of heat shock proteins in Behcet's disease. Clin Exp Rheumatol (2003) 21(Suppl 30):S44-8.

110. Aggarwal A, Chag M, Sinha N, Naik S. Takayasu's arteritis: role of Mycobacterium tuberculosis and its $65 \mathrm{kDa}$ heat shock protein. Int J Cardiol (1996) 55(1):49-55. doi:10.1016/0167-5273(96)02660-5

111. Hermon-Taylor J, Bull T. Crohn's disease caused by Mycobacterium avium subspecies paratuberculosis: a public health tragedy whose resolution is long overdue. J Med Microbiol (2002) 51(1):3-6.

112. Hermon-Taylor J. Treatment with drugs active against Mycobacterium avium subspecies paratuberculosis can heal Crohn's disease: more evidence for a neglected public health tragedy. Dig Liver Dis (2002) 34(1):9-12. doi:10.1016/ S1590-8658(02)80052-4

113. De Buck J, Shaykhutdinov R, Barkema HW, Vogel HJ. Metabolomic profiling in cattle experimentally infected with Mycobacterium avium subsp. paratuberculosis. PLoS One (2014) 9(11):e111872. doi:10.1371/journal. pone. 0111872

114. Gitlin L, Borody TJ, Chamberlin W, Campbell J. Mycobacterium avium ss paratuberculosis-associated diseases: piecing the Crohn's puzzle together. JClin Gastroenterol (2012) 46(8):649-55. doi:10.1097/MCG.0b013e31825f2bce 
115. Feller M, Huwiler K, Schoepfer A, Shang A, Furrer H, Egger M. Longterm antibiotic treatment for Crohn's disease: systematic review and metaanalysis of placebo-controlled trials. Clin Infect Dis (2010) 50(4):473-80. doi:10.1086/649923

116. Available from: http://clinicaltrials.gov/ct2/show/NCT01951326?term=rhb104\&rank=2 last viewed 11.12.14

117. Available from: http://clinicaltrials.gov/ct2/show/NCT01717664?term=rhb104\&rank=1 last viewed 11.12.14

Conflict of Interest Statement: The authors declare that the research was conducted in the absence of any commercial or financial relationships that could be construed as a potential conflict of interest.
Received: 25 November 2014; accepted: 18 February 2015; published online: 04 March 2015.

Citation: Sechi LA and Dow CT (2015) Mycobacterium avium ss. paratuberculosis Zoonosis - The Hundred Year War - Beyond Crohn's Disease. Front. Immunol. 6:96. doi: 10.3389/fimmu.2015.00096

This article was submitted to Mucosal Immunity, a section of the journal Frontiers in Immunology.

Copyright (C) 2015 Sechi and Dow. This is an open-access article distributed under the terms of the Creative Commons Attribution License (CC BY). The use, distribution or reproduction in other forums is permitted, provided the original author(s) or licensor are credited and that the original publication in this journal is cited, in accordance with accepted academic practice. No use, distribution or reproduction is permitted which does not comply with these terms. 